\title{
CICLO DE PALESTRAS DA ASSOCIAÇÃO DE PROFESSORES DE LÍNGUA E LITERATURA (APLL/FFLCH/USP)
}

\author{
Beatriz Daruj Gil *
}

A APLL - Associação de Professores de Língua e Literatura, vinculada ao Departamento de Letras Clássicas e Vernáculas, da FFLCH/USP, realizou no dia 16 de setembro de 2006, no ITAÚ CULTURAL, sito à Av. Paulista, 149, uma jornada com especialistas em Língua Portuguesa, Literatura e Ensino, tendo em vista a possibilidade de reunir seus associados para um debate que pudesse tocar em questões que inquietam ou que conduzem ao aprimoramento das atividades em sala de aula. Nesse sentido, foram convidados professores da Universidade de São Paulo que levaram à discussão o resultado de suas pesquisas atuais.

Destacaram-se, em torno de questões lingüísticas, palestras direcionadas à variação, proferida pela Prof ${ }^{a}$ Livre-docente Dr ${ }^{a}$ Marli Quadros Leite, intitulada "Português Culto e Português Popular: Pontos de contato", em que se discutiu o uso da língua portuguesa no Brasil, observando-se a importância da adequação do uso ao contexto; nisto, localiza-se a possibilidade de usuários que dominam a norma culta, empregarem também a norma popular em situações mais distensas. Trata-se, conforme ressaltou a professora, de um emprego denominado por Dino Preti ( ), norma geral.

A Professora abordou também a questão do preconceito lingüístico e salientou a necessidade de os professores o abandonarem em prol de um novo conceito, o do respeito à pluralidade e à percepção da riqueza localizada nos diversos falares regionais, locais por toda a extensão de nosso país.

A seguir, a Prof ${ }^{a} \operatorname{Dr}^{a}$ Helena Hatsue Nagamine Brandão, especialista em Análise do Discurso, proferiu a palestra "Discurso, Texto e Gêneros", em que apresentou conceitos em torno dos termos texto e discurso, observando a circulação de textos na escola, como ponto de interesse às aulas de produção num sentido amplo que abrange leitura e escrita. Direcionou sua apresentação aos gêneros do discurso e à importância da teoria dialógica de Bakhtin, delineada a partir da significação que adquirem os enunciados (portanto, reais) que circulam em sociedade e que se estabilizam e, assim, podem ser reconhecidos em seus diversos gêneros, como cartas , artigos de opinião, artigos científicos, editorias, notícias, receitas culinárias, orações etc.

A palestra seguinte, "A Prática de Produção de Textos no Ensino Médio", foi proferida pela Prof ${ }^{a}$ Dr $^{a}$ Maria Valíria Aderson de Mello Vargas. A professora procedeu ao levantamento de estatísticas a respeito da produção de alunos que finalizam o ensino médio. Centralizou suas observações nas atividades.

Na palestra: "Leitura: das instruções presentes no texto, à formação do leitor" , o Prof Dr Valdir Heitor Barzotto, destacou estratégias que podem ser aplicadas em sala de aula e que contribuem para a motivação dos alunos e, conseqüentemente, para a formação

\footnotetext{
* Prof ${ }^{a}$ Dra $^{a}$ da Área de Filologia e Língua Portuguesa/DLCV/FFLCH/USP
} 
do leitor. Ressaltou que o professor deve auxiliar seus alunos na busca das instruções que o texto traz consigo. Muitas vezes, marcas explícitas que dão direção à leitura, para que se trilhe o caminho que leve a determinada compreensão.

Responsável pela aplicação das provas do ENEM em São Paulo, o Prof Dr Reginaldo Pinto de Carvalho trouxe toda sua experiência para tratar da "A contribuição do ENEM para o ensino de Língua Portuguesa", título da palestra que proferiu aos associados.

Finalizando a jornada, foi proferida a palestra "Literatura Infantil/Juvenil e Temas Transversais" pelo Prof Dr José Nicolau Gregorin Filho, pesquisador de questões específicas a essa área do conhecimento. 